\title{
PEMBUATAN MIKROKAPSUL MINYAK JERUK (Citrus aurantifolia) UNTUK APLIKASI PADA PENYEMPURNAAN TEKSTIL
}

\author{
PREPARATION OF Citrus aurantifolia OIL MICROCAPSULES \\ FOR APPLICATION IN TEXTILE FINISHING
}

\author{
Tatang Wahyudi ${ }^{1}$, Agus Surya Mulyawan¹, Cica Kasipah", Untung Prayudie', Euis Julaeha² \\ ${ }^{1}$ Balai Besar Tekstil \\ E-mail: texirdti@bdg.centrin.net.id \\ ${ }^{2}$ Fakultas MIPA UNPAD \\ E-mail: fmipa@unpad.ac.id
}

Tanggal diterima: 8 Maret 2017, direvisi: 4 Oktober 2017, disetujui terbit: 2 November 2017

\begin{abstract}
ABSTRAK
Pada penelitian ini telah dilakukan destilasi minyak kulit jeruk nipis (Citrus aurantifolia) dengan menggunakan alat hidrodestilasi Stahl dan pembuatan mikrokapsulnya menggunakan polimer etil selulosa. Metode pembuatan mikrokapsul yang digunakan adalah difusi solven-emulsi/coacervation, dengan memvariasikan rasio minyak terhadap air $(o / w)$ dan rasio core/shell sementara penggunaan jumlah emulsifier tween 80 dan PVA masingmasing sebesar $2 \%$ dan $0,8 \%$. Karakterisasi minyak jeruk nipis dilakukan menggunakan GC-MSD dan spektrofotometer, sedangkan morfologi mikrokapsul menggunakan SEM. Hasil percobaan menunjukkan bahwa minyak kulit jeruk nipis mengandung komponen utama 1-limonen dengan serapan maksimum teramati pada $\lambda=296$ $\mathrm{nm}$. Kondisi percobaan optimum pembuatan mikrokapsul tercapai pada rasio o/w $=1: 20$ dan rasio core/shell= 2:1,5. Ukuran mikrokapsul minyak jeruk nipis sangat random berkisar 17,9 hingga 120,6 $\mu \mathrm{m}$.
\end{abstract}

Kata kunci: Mikrokapsul, etil selulosa, minyak jeruk nipis, coacervation

\begin{abstract}
Isolation of lime peel oil (Citrus aurantifolia) using Stahl hydrodistillation and its microencapsulated form with ethyl cellulose have been conducted. The method used in microcapsules fabrication was emulsion solvent diffusion/ coacervation, by varying the ratio of oil to water $(o / w)$ and the ratio of core / shell while the amount of the emulsifier tween 80 and PVA were $2 \%$ and $0.8 \%$ respectively. Lime peel oil characterization was performed using GC-MSD and spectrometer UV-Vis, while the morphology of microcapsules using SEM. The results showed that the lime peel oil contains 1-limonene as main component and its maximum absorption was observed at $\lambda=296$ $\mathrm{nm}$. The optimum conditions of microencapsulation process were achieved in ratio o $/ \mathrm{w}=1: 20$ and ratio of core / shell $=2$ : 1.5. The size of lime oil microcapsules very random ranged from 17.9 to $120.6 \mu \mathrm{m}$.
\end{abstract}

Keywords: Microcapsule, ethyl cellulose, lime peel oil, coacervation

\section{PENDAHULUAN}

Penggunaan material/ bahan kimia terkapsulasi untuk proses penyempurnaan tekstil beberapa dekade belakangan ini telah berkembang dengan tujuan untuk menghasilkan tekstil dan produk tekstil dengan performa serta fungsi tertentu yang dapat dimanfaatkan oleh konsumen. Pembuatan tekstil yang beraroma wewangian banyak dikembangkan dalam memenuhi gaya hidup dan kesehatan manusia. Disamping memberikan wangi, zat pewangi tersebut juga mempunyai fungsi medis yang biasanya disebut aromaterapi. ${ }^{1}$ Jenis wewangian yang digunakan dalam proses finishing tekstil antara lain seperti minyak bunga ros, lavender, minyak jeruk dan lain-lain.

Zat pengharum tekstil seperti minyak bunga mawar, lavender, minyak jeruk dan lain-lain yang digunakan banyak terdapat di alam yakni berasal dari tumbuhan yang berupa minyak atsiri (essential oil). Minyak atsiri merupakan campuran senyawa aroma volatile kompleks yang dihasilkan oleh tanaman tertentu sebagai metabolit sekunder, yang secara kimia tersusun atas senyawa mono dan seskuiterpen serta polipropanoid aromatik. Minyak atsiri disintesis oleh tumbuhan melalui jalur asam mevalonat untuk senyawa terpen, sedangkan 
polipropanoid melalui jalur asam sikimat (shikimic acid). Tumbuhan yang menghasilkan minyak atsiri diantaranya jeruk, pepermin, kayu manis, kayu putih dan lain-lain. ${ }^{2,3}$

Penambahan zat pewangi ke dalam tekstil telah lama dilakukan dalam bentuk kondisioner yang ditambahkan pada proses pencucian atau pengeringan kain, namun demikian cara seperti ini memberikan efek wangi yang relatif tidak lama berkisar satu sampai dua kali pencucian saja. ${ }^{4} \mathrm{Zat}$ pewangi yang bersifat volatil akan cepat hilang, oleh sebab itu para peneliti tertarik untuk mencari cara agar dapat mengontrol zat pewangi pada tekstil tidak cepat hilang. Pada saat ini saat ini salah satu teknik yang banyak dikembangkan adalah mikroenkapsulasi. Mikroenkapsulasi adalah sebuah teknik pengemasan zat aktif/ zat pewangi sedemikian rupa sehingga menjadi tersalut oleh suatu polimer tertentu, sehingga zat aktif/ pewangi tersebut dapat keluar secara terkontrol dan perlahan-lahan (time release)., ${ }^{5,6}$ Karakteristik mikropartikel yang dihasilkan sangat bergantung pada sifat bahan polimer kulit kapsul yang digunakan. Polimer kulit kapsul harus stabil, inert terhadap bahan yang dikapsulasikan (core), tidak higroskopik serta mampu membentuk film yang bersifat kohesif terhadap core dengan kekuatan, fleksibilitas, stabilitas dan sebagainya sesuai dengan yang diinginkan. ${ }^{8}$

Pada penelitian ini telah dilakukan pembuatan mikrokapsul minyak jeruk nipis (Citrus aurantifolia). Sebagai bahan kulit (shell) kapsul digunakan polimer etil selulosa. Minyak jeruk nipis dipilih dikarenakan minyak ini disamping berbau harum menyegarkan, juga cukup banyak dilaporkan mempunyai aktivitas mengusir serangga, sedangkan etil selulosa merupakan polimer selulosa yang mempunyai kompatibilitas yang baik jika digunakan bersama-sama dengan resin atau crosslinking agent yang biasa digunakan dalam proses penyempurnaan tekstil. Teknik mikroenkapsulasi yang digunakan dalam penelitian ini adalah cara coacervation, mengingat teknik ini merupakan teknik enkapsulasi yang paling sederhana untuk dikerjakan dibandingkan dengan teknik enkapsulasi lainnya. Ruang lingkup penelitian meliputi isolasi minyak dari kulit jeruk nipis serta karakterisasi mikrokapsul yang dihasilkan.

\section{METODE \\ Bahan}

Bahan yang digunakan pada penelitian ini meliputi kulit jeruk nipis untuk diisolasi minyaknya sebagai bahan core kapsul dan bahan kimia seperti etil selulosa ethocel (produk HIMEDIA) viskositas 18-24 cP sebagai bahan kulit (shell) kapsul, polivinil alkohol (PVA) teknis, emulsifier tween 80 teknis serta pelarut etil asetat teknis.

\section{Peralatan}

Peralatan utama yang digunakan meliputi alat destilasi Stahl, pengaduk magnetik, alat filtrasi merk miliphore, GCMSD merk Agilent tipe 7890A/5975C, scanning electron microscopy (SEM) merk JEOL tipe JSM-6510, spektrometer UV-Vis merk Perkin-Elmer tipe Lambda 35.

\section{Prosedur \\ Preparasi minyak jeruk nipis}

Minyak kulit jeruk nipis (C. Aurantifolia) diperoleh melalui proses penyulingan secara destilasi uap menggunakan metode Stahl. Pertamatama buah jeruk nipis dicuci dengan alkohol untuk menghilangkan insektisida dan fungisida yang mungkin terdapat pada permukaan kulitnya, kemudian dibilas dengan air sampai bersih.. Selanjutnya buah jeruk nipis dikupas untuk memisahkan kulitnya. Kulit jeruk nipis yang telah dipotong-potong berukuran $\pm 2 \mathrm{~cm}$ sebanyak 500 gram didestilasi uap selama 8 jam. Minyak yang diperoleh ditampung dalam botol gelas bertutup rapat dan disimpan di lemari pendingin.

\section{Karakterisasi minyak jeruk nipis}

Minyak jeruk nipis dikarakterisasi meliputi berat jenis menggunakan piknometer, indeks bias dengan refraktometer dan pajang gelombang maksimum, $\lambda_{\text {maks }}$ menggunakan spectrometer UVVis. Komponen kimia minyak jeruk dianalisis menggunakan GCMSD dengan kolom kapiler DB 35ms dengan panjang $30 \mathrm{~m}$, diameter kolom 0,25 mm dengan ketebalan film fasa cair 0,25 mikron. Analisis berlangsung dengan pemrograman temperatur dari $50-250^{\circ} \mathrm{C}$ dengan kecepatan kenaikan temperatur $3,5^{\circ} \mathrm{C} /$ menit, temperatur injektor $250^{\circ} \mathrm{C}$, dan jumlah minyak yang diinjeksikan sebanyak $1 \mu \mathrm{L}$.

\section{Pembuatan mikrokapsul minyak jeruk nipis}

Pembuatan mikrokapsul minyak jeruk nipis dilakukan dengan cara yang telah dilakukan oleh Wang dkk. (2009) terdiri 2 tahap proses yaitu proses pembuatan emulsi minyak jeruk nipis dalam air $(\mathrm{O} / \mathrm{W})$ dan proses pembentukan mikrokapsul minyak jeruk nipis. ${ }^{1}$

Pada tahap proses pembuatan larutan emulsi $\mathrm{O} / \mathrm{W}$, etil selulosa dilarutkan dalam pelarut etilasetat dengan perbandingan tertentu dan diaduk menggunakan magnetic stirrer hingga larut. Kemudian tambahkan sejumlah volume jeruk nipis dan aduk kembali hingga bercampur homogen. Larutan ini dinamakan larutan fasa minyak.Larutkan sejumlah polivinil alkohol (PVA) dalam pelarut air yang telah dijenuhkan dengan etilasetat (10\%), kemudian tambahkan emulsifier Tween 80. Larutan ini dinamakan larutan fasa air. Masukkan larutan fasa minyak ke dalam larutan fasa air secara perlahan-lahan sambil terus diaduk. 
Rasio fasa minyak terhadap fasa air divariasikan dari mulai 1;10; 1:15; 1:20; dan 1:25. Sedangkan variasi rasio minyak jeruk (core) terhadap kulit kapsul nya (shell) etil selulosa adalah: 2:1; 2:1,5; 2:2; dan 2:2,5.

Proses pembentukan mikrokapsul dilakukan dengan cara memasukkan larutan emulsi $\mathrm{O} / \mathrm{W}$ secara perlahan-lahan ke dalam air secara bertahap sambil terus dilakukan pengadukan dengan menggunakan magnetic stirrer dengan kecepatan konstan. Secara perlahan akan tampak deposit mikrokapsul minyak jeruk nipis yang berwarna putih. Kemudian dilakukan penyaringan menggunakan kertas saring dan pencucian terhadap mikrokapsul dengan menggunakan air.

\section{Pengamatan mikrokapsul menggunakan SEM}

Terhadap mikrokapsul hasil percobaan dilakukan pengamatan morfologinya dengan menggunakan scanning electron microscope (SEM). Sedikit sampel mikrokapsul hasil percobaan diletakkan di atas permukaan sample holder yang terbuat dari logam kuningan, kemudian dilakukan proses coating/ pelapisan menggunakan logam platina, maka sampel siap diamati dengan SEM.Proses pengamatan dengan SEM dilakukan pada $5 \mathrm{kV}$ dan perbesaran dibawah $100 \mathrm{X}$.

\section{Penentuan kapasitas oil content mikrokapsul}

Kapasitas oil content mikrokapsul ditentukan dengan cara menimbang sejumlah mikrokapsul, kemudian dimasukkan ke dalam mortar dan ditambahkan sejumlah volume etanol lalu digerus, dan didiamkan beberapa saat kemudian saring dengan menggunakan kertas saring. Filtrat diukur dengan spektro UV-Vis pada $\lambda_{\text {maks }}$ minyak jeruk nipis. Kemudian nilai absorban yang diperoleh diplotkan ke dalam kurva kalibrasi absorban terhadap konsentrasi minyak jeruk nipis yang telah dibuat sebelumnya.

\section{HASIL DAN PEMBAHASAN \\ Karakteristik minyak jeruk nipis}

Proses preparasi minyak kulit jeruk nipis dengan menggunakan teknik penyulingan hidrodestilasi menggunakan metode Sthal. Karakterisasi minyak jeruk nipis hasil destilasi dapat dilihat pada Tabel 1. Minyak atsiri yang dihasilkan memiliki kualitas cukup baik. Secara organoleptis minyak yang dihasilkan berwarna kuning agak kehijauan serta berbau sangat harum. Rendemen minyak atsiri yang diperoleh sebesar $0,83 \%$.Hasil penentuan berat jenis destilat minyak jeruk nipis pada $25^{\circ} \mathrm{C}$ adalah 0,8549 dan indeks biasnya 1,4756. Dengan demikian minyak jeruk nipis hasil destilasi memiliki kualitas tergolong baik apabila dibandingkan terhadap persyaratan mutu nya, dimana nilai berat jenis minyak jeruk yang baik berkisar 0,854-0,859, sedangkan nilai indeks bias minyak kulit jeruk nipis yang baik berkisar 1,4750 - 1,4770 pada temperatur $20^{\circ} \mathrm{C} .{ }^{9}$

Tabel 1. Karakteristik minyak jeruk nipis

\begin{tabular}{lc}
\hline Parameter & Nilai/deskripsi \\
\hline Warna & Kuning kehijauan \\
Rendemen & $0,83 \%$ \\
Berat jenis $\left(25^{\circ} \mathrm{C}\right)$ & 0,8549 \\
Indeks bias & 1,4756 \\
\hline
\end{tabular}

Gambar 1 adalah hasil scanning minyak kulit jeruk nipis menggunakan spektrometer UV-Vis. Proses scanning dilakukan pada rentang panjang gelombang $200-700 \mathrm{~nm}$. Tampak teramati bahwa minyak kulit jeruk nipis mempunyai serapan maksimum pada panjang gelombang $296 \mathrm{~nm}$.

\section{Analisis minyak jeruk nipis}

Susunan kimia dan mutu minyak atsiri dapat bervariasi, tergantung dari kondisi iklim dan tanah tempat tumbuh, tingkat kematangan, perbedaan cara penyulingan yang digunakan dan lamanya penyimpanan. Varietas yang sama, lingkungan yang berlainan akan mempengaruhi rendemen minyak dan dengan sendirinya susunan minyak pun akan berbeda.

Minyak atsiri mengandung sejumlah senyawa kimia hidrokarbon, alkohol, ester, aldehida, keton, oksida lakton, kadang-kadang senyawa nitrogen dan sulfur, dan senyawa nonvolatil. Komposisi kimia minyak atsiri selain ditentukan oleh kondisi lingkungan juga dapat dipengaruhi oleh faktor genetik yang akan menghasilkan sistem enzim yang khas pada pengaturan kelenjar ${ }^{9}$.

Untuk mengetahui konstituen penyusun minyak atsiri kulit jeruk tersebut maka minyak atsiri diinjeksikan ke dalam alat paduan kromatografi gas-spektroskopi massa (GC-MSD). Hasil pengukuran GCMSD terlihat pada Gambar 2 dan Tabel 1. Berdasarkan data base/NIST11.L yang terdapat pada alat GC-MSD yang digunakan pada pengukuran ini diperoleh konstituen penyusun minyak kulit jeruk nipis (C. aurantifolia) seperti ditunjukkan pada Tabel 2. Dari Tabel 2 terlihat bahwa dalam minyak jeruk nipis terkandung berbagai komponen kimia. Empat komponen utama penyusun minyak atsiri kulit jeruk nipis (C. aurantifolia) berturut-turut adalah D-Limonen (tr $=10,445$ '; 38,94\%), $\beta$-pinen (tr = 8,334'; 26,66\%), $\alpha$-terpineol (18,697'; 8,29\%), dan terpinen-4-ol $(17,689 ' ; 4,32)$ sedangkan komponen kimia lainnya mempunyai luas puncak di bawah 5\%. Hampir semua minyak atsiri kulit buah jeruk nipis mengandung komponen utama limonen dan $\beta$-pinen seperti yang dilaporkan oleh Simas et al. (2017) dengan komposisi empat komponen utama yaitu Dlimonen $(31,1 \%), \quad \gamma$-terpinen $(10,8 \%)$, geranial 
(9,6\%), dan $\beta$-pinen (8,5\%). Sedangkan Foud H. A., et al (2017) melaporkan D-limonen (38,9\%), $\beta$ -
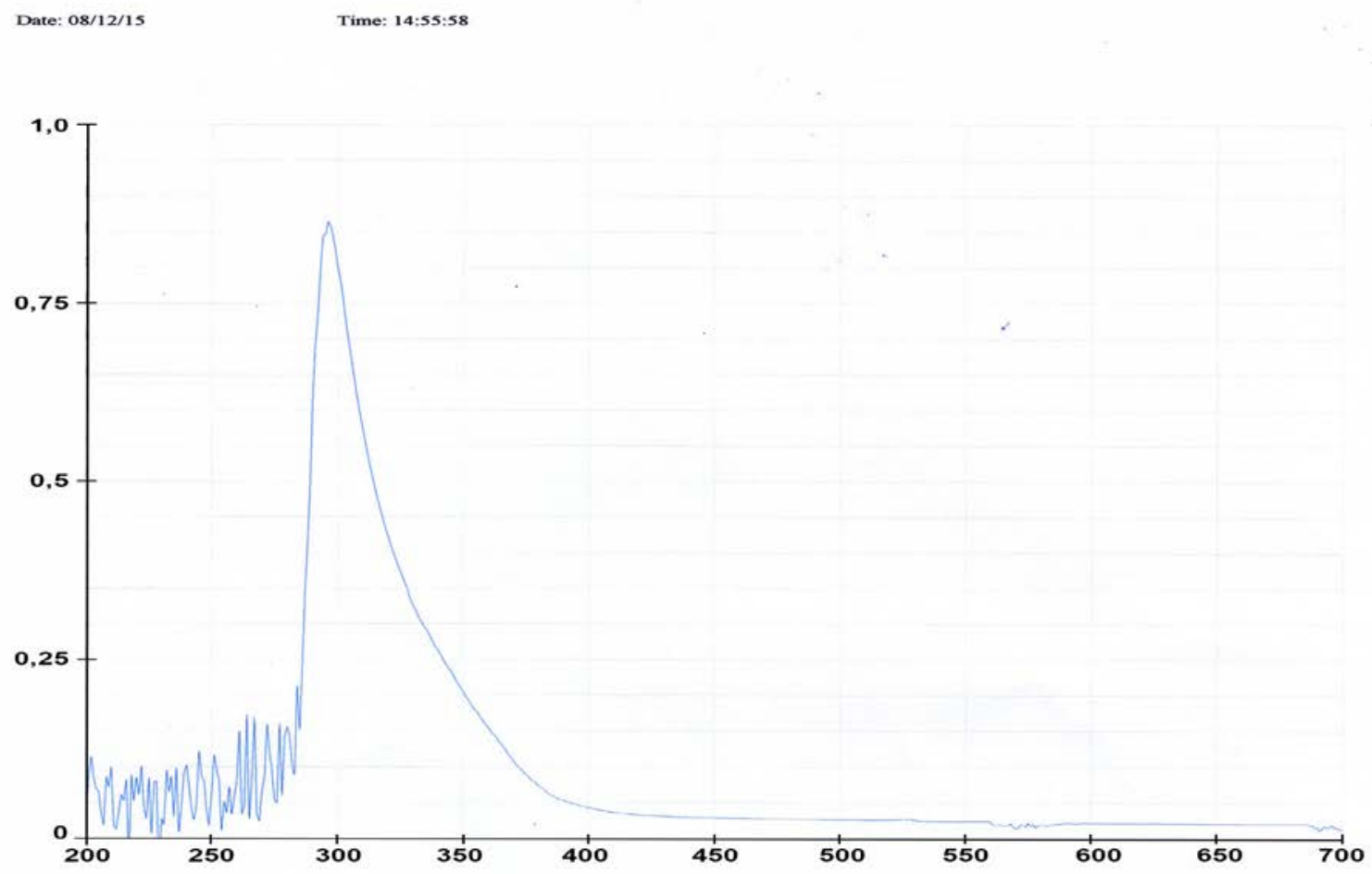

JERUK:SP - 08/12/15 - jeruk nipis 1

Gambar 1. Hasil penentuan $\lambda_{\text {maksminyak jeruk nipis menggunakan spectrometer } U V-V i s}$

\section{Pembuatan mikrokapsul minyak jeruk nipis}

Dalam pembuatan mikrokapsul minyak jeruk nipis yang dilakukan banyak variable yang berpengaruh terhadap mikrokapsul yang dihasilkan seperti pengaruh ratio fasa minyak terhadap fasa air, rasio minyak (core) terhadap kulit kapsul (shell), jumlah emulsifier dan pengadukan.

Ratio fasa minyak terhadap fasa air merupakan variable yang sangat penting dalam pembuatan mikrokapsul. Pada penelitian ini pembuatan mikrokapsul etil selulosa dilakukan pada kecepatan pengadukan tetap yakni $600 \mathrm{rpm}$ dan jumlah emulsifier sebesar $1 \%$, sedangkan ratio fasa minyak terhadap fasa air divariasikan dari mulai $1 ; 10 ; 1: 15 ; 1: 20$; dan 1:25. Pada ratio o/w 1:10 kapasitas pengisian kapsul (oil content) berkisar $40 \%$ kemudian meningkat hingga rasio fasa minyak dan fasa air $=1: 20$, sedangkan pada rasio o/w 1:25 kapasitas pengisian kapsul kembali turun, hal ini kemungkinan disebabkan pada kondisi ini ukuran butiran-butiran minyak yang terbentuk dalam sistem emulsi akan semakin kecil sehingga kandungan jumlah minyak dalam mikrokapsul akan semakin berkurang pula. Sebaliknya apabila fasa minyak terlalu besar maka fasa minyak tersebut akan sulit teremulsi dengan baik dalam fasa air, butir-butir minyak dalam sistem emulsi sulit untuk menyebar dalam fasa air atau akan terjadi proses pinen (10,2\%), p-mertha (5,7\%), dan $\gamma$-terpineol $(5,2 \%)$. 
Abundance

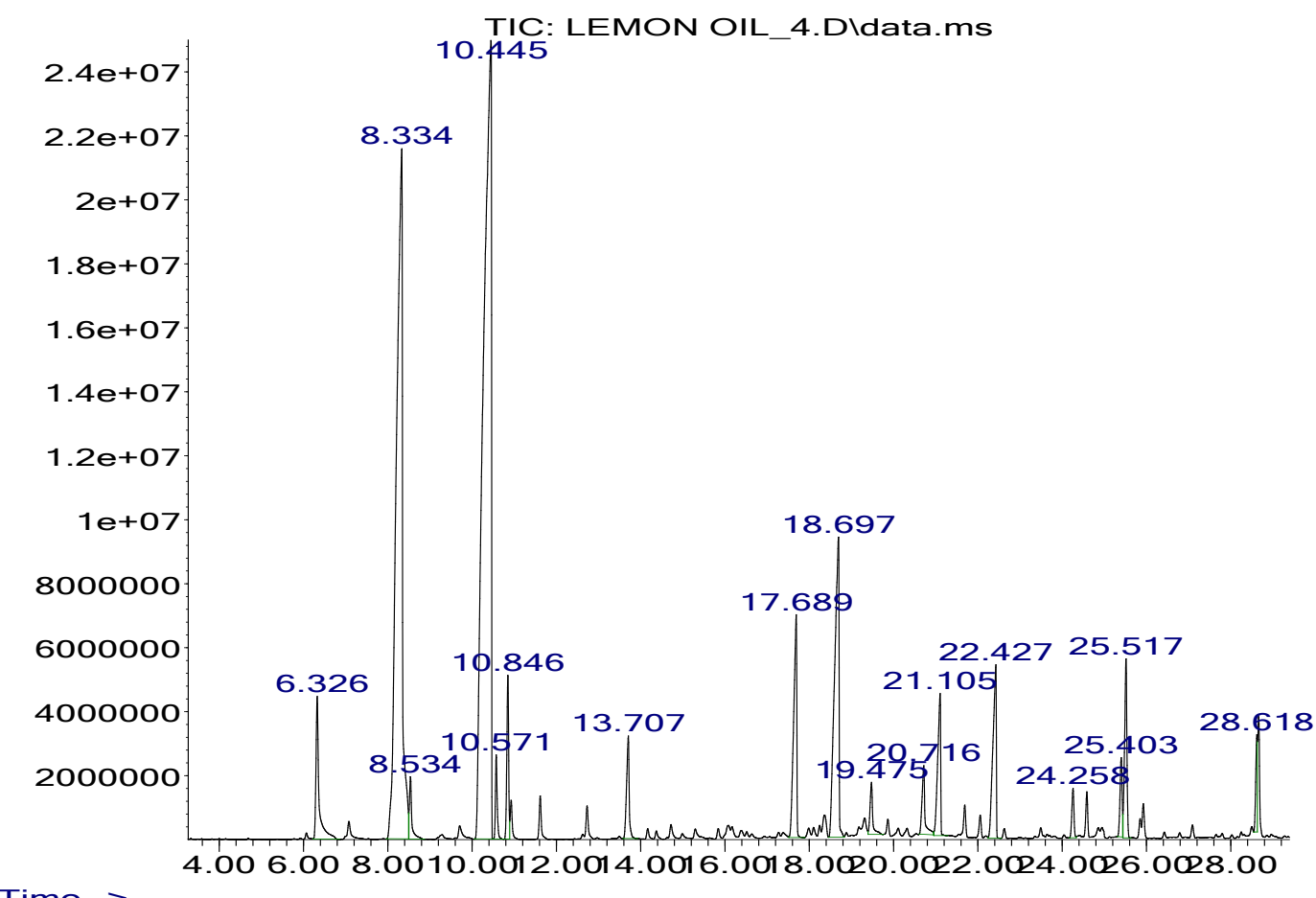

Gambar 2. Kromatogram minyak kulit jeruk

Tabel 2. Komposisi kimia minyak atsiri kulit jeruk nipis (C. aurantifolia)

\begin{tabular}{|c|c|c|c|c|}
\hline No. & $\underset{\text { (menit) }}{\text { tr }}$ & $\begin{array}{c}\text { Luas } \\
\text { (\%) }\end{array}$ & Nama senyawa & Kualitas \\
\hline 1. & 6,326 & 2,79 & $\begin{array}{l}\text { (1R)-2,6,6-trimetilbisiklo[3.1.1] } \\
\text { hept-2-ena }\end{array}$ & 96 \\
\hline 2. & 8,334 & 26,66 & $\beta$-Pinen & 95 \\
\hline 3. & 8,534 & 0,92 & $\beta$-Mirsen & 91 \\
\hline 4. & 10,445 & 38,94 & D-Limonen & 96 \\
\hline 5. & 10,571 & 0,94 & $\beta$-Phellandren & 91 \\
\hline 6. & 10,846 & 1,88 & o-Simen & 97 \\
\hline 7. & 13,707 & 1,67 & 1,6-Oktadien-3-ol, 3,7-dimetil- & 97 \\
\hline 8. & 17,689 & 4,32 & Terpinen-4-ol & 95 \\
\hline 9. & 18,697 & 8,29 & $\alpha$-Terpineol & 86 \\
\hline 10. & 19,475 & 0,88 & $\begin{array}{l}\text { 2,6-Oktadien-1-ol, } \\
\text { (Z) }\end{array}$ & 96 \\
\hline 11. & 20,716 & 1,26 & Geraniol & 97 \\
\hline 12. & 21,105 & 2,61 & 2,6-Oktadienal, 3,7-dimethil-, (Z) & 93 \\
\hline 13. & 22,427 & 3,61 & Sitral & 96 \\
\hline 14. & 24.258 & 0,65 & $\begin{array}{l}\text { Sikloheksan, 1-etenil-1-metil-2, } \\
\text { 4-bis(1-metiletenil)-, [1S- } \\
(1 \alpha, 2 \beta, 4 \beta)]-\end{array}$ & 91 \\
\hline 15. & 25,403 & 1,05 & $\begin{array}{l}\text { Bisiklo[3.1.1]hept-2-ena, 2,6- } \\
\text { dimetil-6-(4-metil-3-pentenil)- }\end{array}$ & 97 \\
\hline 16. & 25,517 & 2,57 & Geranil acetate & 74 \\
\hline 17. & 28,618 & 0,98 & $\beta$-Bisabolen & 93 \\
\hline
\end{tabular}

\section{Morfologi mikrokapsul}

Hasil karakterisasi mikrokapsul menggunakan scanning electron microscope (SEM) dengan perbesaran 65 kali dapat dilihat pada Gambar 5. Tampak mikrokapsul minyak jeruk nipis berbentuk bulat, dimana ukuran partikel 
mikrokapsul pada kondisi optimum pembuatannya memperlihatkan ukuran yang beragam dimana ukuran mikrokapsul terkecil 17,9 $\mu \mathrm{m}$ sedangkan yang terbesar berukuran 120,6 $\mu \mathrm{m}$.

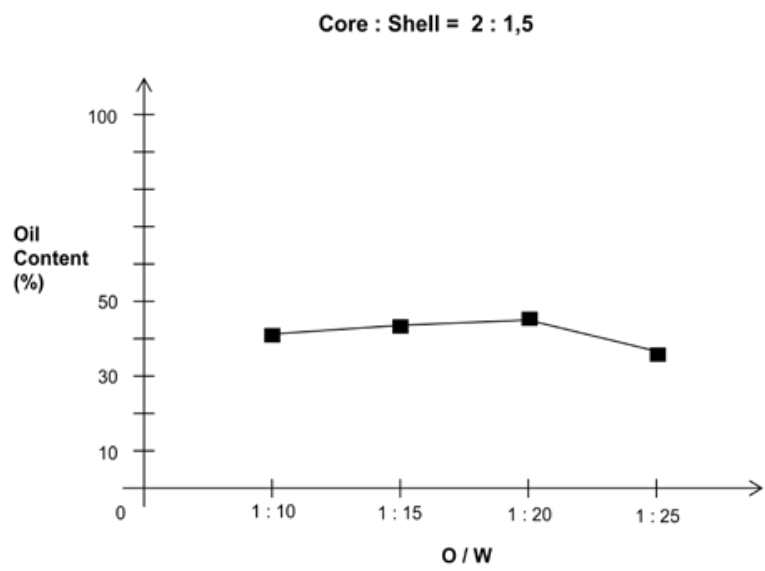

Gambar 3. Kandungan minyak jeruk dalam mikrokapsul terhadap variasi ratio minyak/air $(\mathrm{O} / \mathrm{W})$

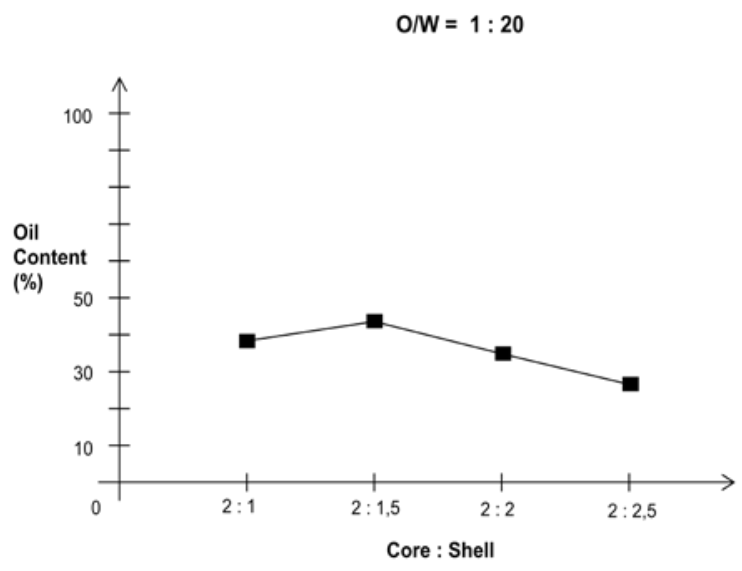

Gambar 4. Kandungan minyak jeruk dalam mikrokapsul terhadap variasi rasio core/shell.

Pada penelitian ini dilakukan pula percobaan awal pencelupan contoh kain katun ke dalam larutan mikrokapsul tanpa bantuan binder. Pengamatan terhadap contoh kain yang telah mengalami perlakuan dengan mikrokapsul tersebut dengan menggunakan SEM dapat dilihat pada Gambar 6. Tampak bahwa partikel mikrokapsul kulit jeruk nipis teramati menempel di permukaan contoh kain kapas dengan penyebarannya yang tidak merata. Upaya yang dapat dilakukan dalam meratakan penyebaran mikrokapsul pada permukaan kain kapas dapat dilakukan dengan cara melakukan beberapa kali pengulangan pencelupan. Pengamatan secara visual dan organoleptik terhadap contoh kain hasil percobaan juga tidak memperlihatkan perubahan tekstur sehingga mikrokapsul hasil sintesis memungkinkan untuk diaplikasikan pada proses penyempurnaan tekstil.

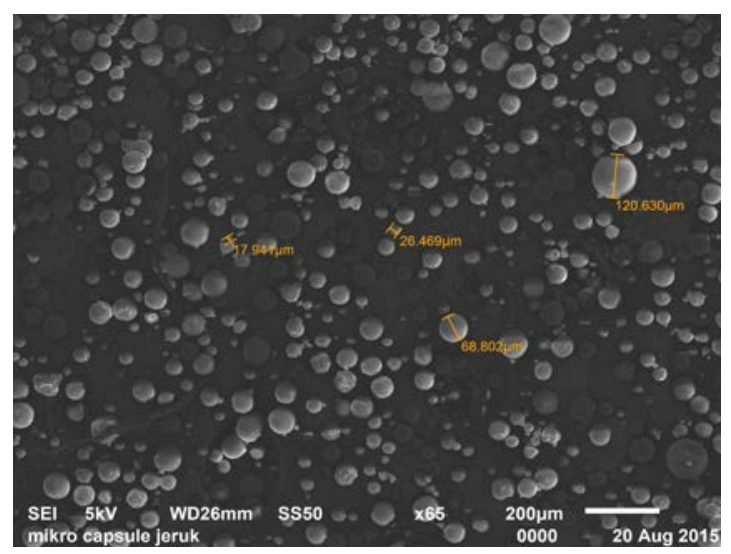

Gambar 5. Hasil pengukuran mikrokapsul minyak jeruk nipis dalam etil selulosa pada perbesaran 65x.

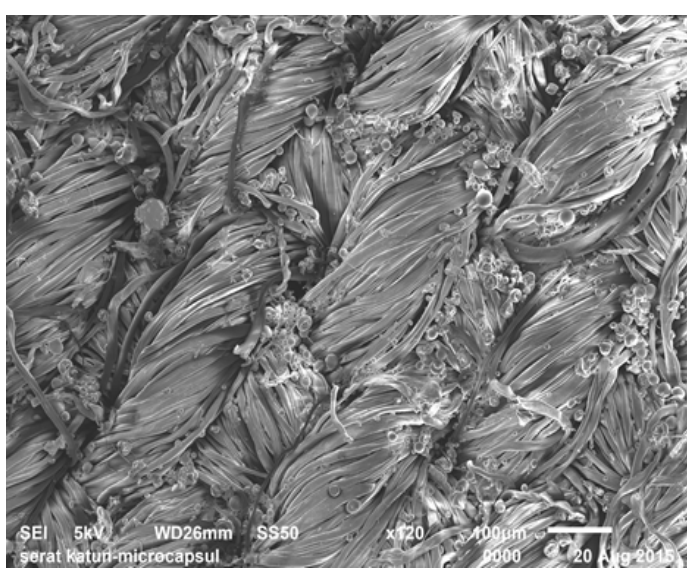

Gambar 6. Hasil pengamatan kain katun yang dicelup dengan larutan mikrokapsul minyak jeruk nipis dalam etil selulosa dengan menggunakan SEM dengan perbesaran 120x.

\section{KESIMPULAN}

Dari penelitian yang telah dilakukan diperoleh beberapa kesimpulan bahwa hasil karakterisasi minyak jeruk nipis hasil destilasi dengan GC-MSD menunjukkan bahwa komponen kimia utamanya adala 1-limonen. Serapan maksimum minyak teramati pada $296 \mathrm{~nm}$. Mikrokapsul minyak jeruk nipis dengan kulit kapsul etil selulosa berhasil disintesis dengan metode coacervation pada kondisi rasio fasa minyak terhadap air $(o / w)=1: 20$ dan rasio core/shell $=2: 1,5$. Mikrokapsul berukuran random mulai dari 17,9-120,6 $\mu \mathrm{m}$ dengan kandungan minyak rata-rata sebesar $45 \%$. 


\section{PUSTAKA}

1. Wang J.M., Zheng W., Song Q.W., Zhu H., \& Zhou Y., Preparation and characterization of natural fragrant microcapsules, Journal of Fiber Bioengineering and Informatics 1, 293299 (2009).

2. Nerio L.S., Verbel J.O., Stashenko E., Repellent activity of essential oils: review, Bioresources Technology. 101, 372-378 (2010).

3. Indonesian essential oils the scents of natural life, Handbook of commodity profile (Deperindag, 2011).

4. Nelson G., Application of microcapsulation in textile, International Journal of Pharmaceutics 242, 55-62 (2002).

5. Jing H., Properties of aroma sustained release cotton fabric with rose fragrance nanocapsule, Chinese Journal of Chemical Engineering. 19, 3, 523-528 (2011).

6. Masango P., Cleaner production of essential oils by steam distillation, Journal of Cleaner Production 13, 833-839 (2005).
7. Martins I. M., Barreiro M.F., Coelho M., Rodrigues A. E., Microencapsulation of essential oils with biodegradable polymeric carriers for cosmetic application-review, Chemical Engineering Journal 245, 191-200 (2014).

8. Ghulam Murtaza, Ethylcellulose Microparticles: A Review, Acta Poloniae Pharmaceutica - Drug Research 69, 11-22 (2012).

9. Guenther E., Minyak Atsiri, Penerbit Universitas Indonesia (1990).

10. Simas, D.L. R., Amorim, S. H. B. M., Goulart, F. R. V., Alviano, C. S., Alviano, D. S., Silva, A. J. R., Citrus Species Essential Oils and Their Components can Inhibit or Stimulate Fungal Growth in Fruit. Industrial Crops and Products 98, 108-115 (2017).

11. Foud, H.A., Camara, C. A. B., Chemical Compotitions and Bioactivity of Peel Oils from Citrus aurantifolia and Citrus reticulata and Enantiomers of Theirs Major Constituents againts Sitophilus zeamais (Coleoptera: curculionidae), Journal of Stored Products Research 73, 30-36 (2017). 
Arena Tekstil Vol. 32 No. 1, 2017: 1-8 